\title{
Effect On Stock Price Of Financial Restatements As A Result Of Revenue Recognition Errors
}

Yiou Zhu, Shanghai Sanda Institute, China Jodi Kleuskens, Rider University, USA

Gloria Grebis, Rider University, USA

\begin{abstract}
Revenue recognition came to the forefront of accounting debates several years ago as a result of the meltdown of high tech and telecommunications companies. Many of these corporations had recognized sales in the current periods for contracts that had future deliverables. This created significant misstatements that made some companies that were actually operating in the red seem as though they were profitable. SAB 101 was issued in December 1999 to clarify the basic framework for the proper timing of revenue. As Lynn Turner of the SEC stated in a May 2001 speech, "It was based on four bedrock principles established by GAAP: 1) persuasive evidence of an arrangement exists, 2) delivery has occurred or services have been rendered, 3) the seller's price to the buyer is fixed or determinable, and 4) collectability is reasonably assured." These guidelines apparently were not clear enough, as more companies were investigated for revenue recognition problems. This led to the issuing of SAB 103 and 104 in late 2003 that further detailed the specifics of when to recognize revenues. SAB 104 focuses on the areas of bill and hold arrangements, immaterial obligations, and nonrefundable up-front fees, and how all these factors affect cost of goods sold and the resulting revenues. The year after the release of SAB 104 saw additional companies restating their revenues in order to comply with the new standards. You would presume that revenue accounting standards would have naturally evolved over all of these releases to straightforward, robust, and consistent across transactions, industries, and countries. Sadly, however, today's revenue accounting standards exhibit none of these qualities, and stakeholders are forced to make poorer economic decisions as a result. By research, we found that the gross amount of the restatement did not affect the stock price as much as other factors. But the largest drops were usually connected to companies where the restatement announcement was coupled with other bad news. Industry differences were more pronounced.
\end{abstract}

Keywords: Revenue Recognition, Earnings Restatement, Financial Statements

\section{INTRODUCTION}

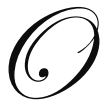

ur research study objective is to determine the effect on stock price with the announcement of a restatement of financial statements due to revenue recognition errors. We located thirty companies that announced that they would restate their earnings between 2007 and 2009 through internet news searches of public announcements and stock price histories. We have sorted the companies by industry, indicated the amount of the restatement, determined their stock price before and after the announcement, and calculated the net change. We found that an announcement of restatement of the financials almost always had a negative effect, and when the drop in stock price was small, it was usually because the company was already at a low stock price level and had had previous negative announcements.

\section{RESEARCH QUESTION}

What is the short term decrease in stock price following the announcement of an earnings misstatement attributed to revenue recognition? 


\section{SAMPLE COLLECTION}

The sample was collected by accessing news archives for the years of 2009 - 2007 from the WallStreetJournal.com, CNN.com, News.Search.Yahoo.com/news, ProQuest database, and News.Google.com. The terms revenue restatement or earnings restatement were searched in headlines of these news articles. The 30 most recent public companies were selected for analysis of the restatement and stock price changes. Figure 1 is the sample analysis of industry differences.

Figure 1: Sample of Industry Differences

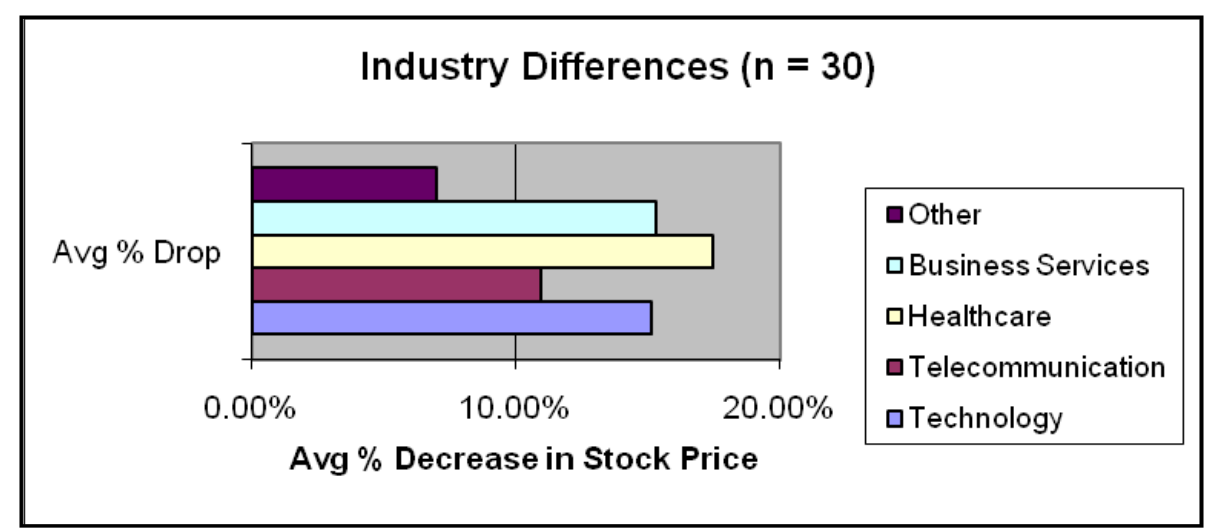

Source: WallStreetJournal.com, CNN.com, News.Search.Yahoo.com/news, ProQuest database, and News.Google.com

\section{BACKGROUND INFORMATION}

In 2005, nearly one out of every 12 U.S. public companies filed an earnings restatement, and revenue recognition issues were the leading cause of such restatements. Furthermore, in a recent survey conducted by RevenueRecongition.com in association with International Data Corporation (IDC) found that $57 \%$ of public companies cannot finalize their revenue numbers within their monthly close process. This survey was conducted by email with 578 business leaders, with $80 \%$ of respondents being CFOs, Controllers, senior finance executives, internal auditors, or compliance leaders. 110 responses consisted of companies with $\$ 1$ billion or more in revenues a year. The percentage of companies that said they were unable to calculate revenue at monthly closes said that they spend on average three weeks in further analysis to uncover corrections or adjustments to their numbers after the books had been officially closed. These companies have attributed these delays to be caused from complex transactions or the lack of required information at the closing of their books. Computer hardware and software manufacturing and utilities companies ranked complex transactions as being their number one issue regarding revenue recognition. In addition, companies with revenue exceeding $\$ 1$ billion acknowledged complex transactions to be a larger issue than that of smaller companies (Revenue 3). Figure 2 is a statistic of reasons for revenue reporting delays.

Revenue recognition is often criticized by the financial community for being perhaps the single greatest problem area in U.S. financial reporting. Within the same study conducted by RevenueRecognition.com and IDC it was discovered that $40 \%$ of all respondents rated revenue as having the greatest risk on their financial statements. The proportion was even higher for companies with more than $\$ 200$ million in revenue. When these respondents were asked about the relative materiality of these potential errors, it was "found that revenue recognition accounting is five times more likely to result in a material error than any other key accounting process." (Risk 3). Figure 3 is a statistic of greatest risk of errors / inaccuracies in the business. 
Figure 2: Reasons for Revenue Reporting Delays

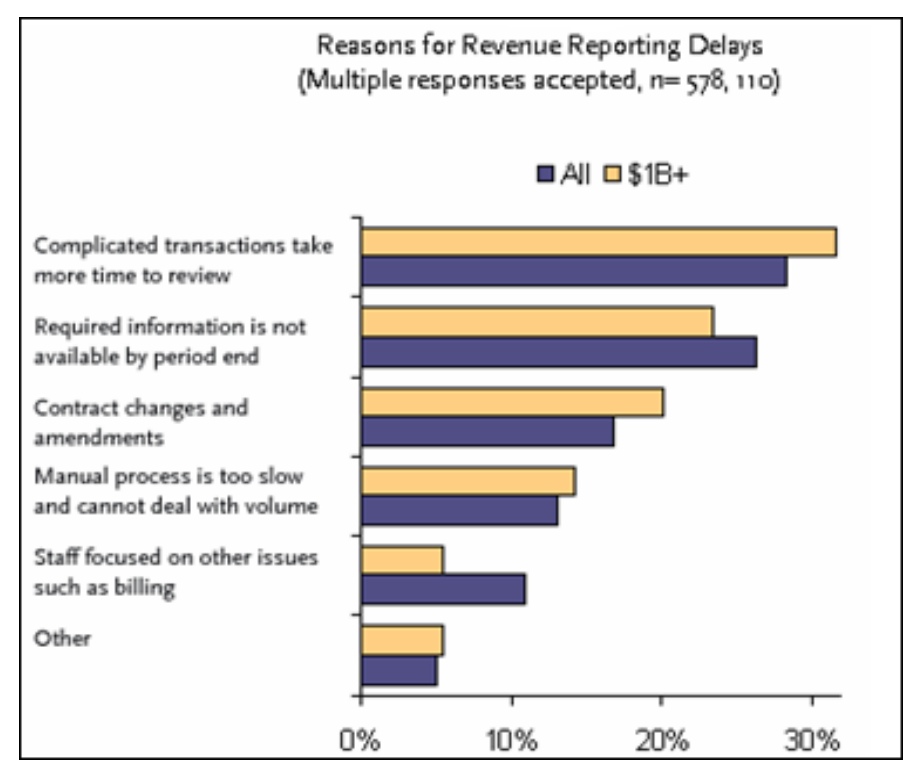

Source: "Best Practices in Revenue Reporting: Revenue Reporting Edition." RevenueRecognition.com. Financial Executive Benchmarking Survey

Figure 3: Greatest Risk of Errors/Inaccuracies in the Business

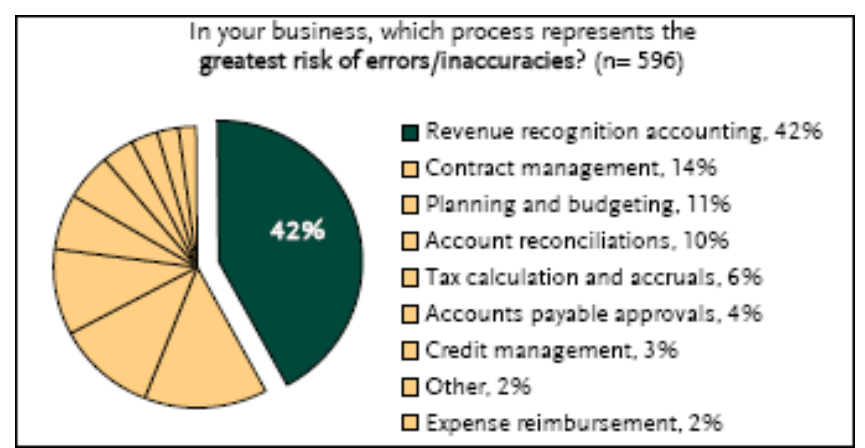

Source: "Risks in Revenue Reporting: Risk Edition."

RevenueRecognition.com. Financial Executive Benchmarking Survey.

Since it is often presumed that revenue is recognized at the time of sale in most industries, some people erroneously conclude that the sale is itself the sole criterion in recognizing revenue. If only the rules were this simple! In response to a long list of revenue recognition problems in the late 1990s, the SEC offered additional guidance to companies on how to properly recognize revenue by issuing Staff Accounting Bulletin (SAB) 101, Revenue Recognition in Financial Statements which was revised in 2003 with SAB 104. At the same time the Sarbanes-Oxley Act of 2002 provided more attention on revenue-related internal controls that several companies had severely needed. Each of these releases was produced to close some loopholes and eliminate gray areas in how GAAP was being applied in practice.

Concept statement 5 states that an "entity's revenue-earning activities involve delivering or producing goods, rendering services, or other activities that constitute its ongoing major or central operations, and revenues are considered to have been earned when the entity has substantially accomplished what it must do to be entitled to the benefits represented by the revenues." The concept continues by explaining that the two conditions of revenue 
recognition are "being realized or realizable and earned". Of course these are very broad definitions and need further explanation. The first condition is the critical event, or the time that goods or services are transferred to a customer for a benefit or gain. The second condition is measurability. A reliable measure is a market price of a product or service or a contractual price established in advance that revenues can be recognized against as time passes (SAB 104). Both conditions must be met before revenue can be recognized.

"In some cases, Conditions 1 and 2 are satisfied before the sale, for example, as production takes place on a long-term construction contract." In this illustration, expenses can also be measurable with a reasonable degree of assurance against revenues to be received, and therefore GAAP allows income to be recognized before the sale. "In other circumstances, Conditions 1 and 2 may not both be satisfied until after the time of the sale, for instance, not until the cash is received on installment sales when considerable uncertainty exists regarding ultimate collection" In this case the revenue should not be recognized until the cash has been received. GAAP instead disallows revenue recognition when the sale occurs and instead defers recognition to until another event takes place; cash is received (Revsine 123). Therefore the SEC believes that revenue can be recognized only when all of the four criteria mentioned in the abstract are met: 1) persuasive evidence of an arrangement exists, 2) delivery has occurred or services have been rendered, 3) the seller's price to the buyer is fixed or determinable, and 4) collectability is reasonably assured.

Unfortunately, some revenue arrangements can embody multiple revenue generating activities, SAB 104 if very helpful in explaining several troublesome transactions and gives the SEC's interpretation on how the transaction should be handled. Below is an explanation of a few of these scenarios and their appropriate treatment.

\section{SCENARIO OF REVENUE RECOGNITION ERRORS}

\section{Scenario 1 - Goods Shipped on Consignment}

A manufacturer, the seller, ships 100,000 of its new product to its distributors for $\$ 50$ per item. Under terms of the signed agreement, distributors have the right (a) to return unsold products (b) not to pay the seller until they resell the product to final customers through retail outlets (c) receive a rebate for any unsold portion. In most cases the manufacturer would want to argue that they can recognize all $\$ 5,000,000$ revenue upon delivery of the goods. Unfortunately for them, the SEC rules that no revenue can be recognized on delivery because the seller has retained the risks and rewards of ownership of the product. The title has not passed to the distributor because this situation does not pass the $4^{\text {th }}$ test above, collectability. It can not be reasonably assured that all 100,000 items will be sold to third parties and not returned or rebated (Revsine 148).

The companies listed in Table 1 had violations related to this type of scenario or other types of bill and hold agreements where revenue should have been recognized at the time of the distributor's sale, not when the company shipped goods to the distributor:

Table 1: Companies that belong to Scenario 1

\begin{tabular}{|l|r|r|r|r|}
\hline \multicolumn{1}{|c|}{ Company Name } & $\begin{array}{c}\text { Amount of } \\
\text { Restatement }\end{array}$ & $\begin{array}{c}\text { Income in } \\
\text { Restatement } \\
\text { Periods }\end{array}$ & $\begin{array}{c}\text { Restate to } \\
\text { Net Income } \\
\text { Ratio }\end{array}$ & $\begin{array}{c}\text { Drop in } \\
\text { Stock } \\
\text { Price }\end{array}$ \\
\hline MRV Communications & N/A & $(\$ 15,622,000)$ & & $26.00 \%$ \\
\hline Verifone & $\$ 70,000,000$ & $(\$ 34,016,000)$ & $205.79 \%$ & $48.80 \%$ \\
\hline WellCareHealth Plans Inc & $\$ 42,000,000$ & $(\$ 26,833,000)$ & $156.52 \%$ & $7.38 \%$ \\
\hline ArthroCare & $\$ 28,000,000$ & $\$ 37,427,500$ & $74.81 \%$ & $42.02 \%$ \\
\hline Skilled Healthcare Group & $\$ 8,000,000$ & $\$ 15,311,600$ & $52.25 \%$ & $19.00 \%$ \\
\hline NutraCea Inc. & $\$ 4,600,000$ & $\$ 11,911,000$ & $38.62 \%$ & $17.14 \%$ \\
\hline Isilon Systems, Inc & $\$ 7,000,000$ & $\$ 62,300,000$ & $11.24 \%$ & $4.10 \%$ \\
\hline EF Johnson & $\$ 3,400,000$ & $(\$ 30,986,000)$ & $10.97 \%$ & $12.50 \%$ \\
\hline Apogee Technology, Inc & $\$ 250,000$ & $\$ 2,952,387$ & $8.47 \%$ & $7.14 \%$ \\
\hline Sunrise Real Estate Group & $\$ 157,811$ & $\$ 4,766,000$ & $3.31 \%$ & $0 \%$ \\
\hline Medicis & Under $\$ 500,000$ & $\$ 70,000,000.00$ & $0.71 \%$ & $26 \%$ \\
\hline
\end{tabular}

Source: WallStreetJournal.com, CNN.com, News.Search.Yahoo.com/news, ProQuest database, and News.Google.com 


\section{Scenario 2 - Sales with delayed delivery}

Prior to the close of Company A, a manufacturer's, fiscal year it completes production of 30,000 chairs. The chairs sell for $\$ 100$ each and were ordered by Customer B that currently can not take delivery of them because of a lack of storage. Company A segregates the chairs awaiting shipment from other unsold inventory in its own warehouse. Company A would like to recognize the $\$ 3,000,000$ now so it can be included in the current fiscal year. The SEC argues that a delivery is not considered to have taken place unless the customer (1) takes control of the title and (2) assumes the risks and rewards of ownership of the products. Typically these conditions are not met until the item in question has been reached the customer or has been received by the customer's place of business. In certain circumstances a "bill and hold" sales agreement can take place when there is a substantial business purpose for doing so and the seller may recognize the revenue when the production of the good has been completed.

Timing issues constituted the largest group of revenue recognition errors. The companies listed in Table 2 are those in our study that made revenue recognition errors related to this scenario. We have also included other issues of including revenue in the wrong period, such as maintenance contracts.

Table 2: Companies that belong to Scenario 2

\begin{tabular}{|c|c|c|c|c|}
\hline Company Name & $\begin{array}{c}\text { Amount of } \\
\text { Restatement }\end{array}$ & $\begin{array}{c}\text { Income in } \\
\text { Restatement } \\
\text { Periods } \\
\end{array}$ & $\begin{array}{c}\text { Restate to } \\
\text { Net Income } \\
\text { Ratio } \\
\end{array}$ & \begin{tabular}{|l|} 
Drop in \\
Stock \\
Price \\
\end{tabular} \\
\hline Insight Enterprises Inc & $\$ 60,000,000$ & $(\$ 39,555,000)$ & $151.69 \%$ & $48.31 \%$ \\
\hline Cadence Design Systems & $\$ 24,800,000$ & $(\$ 16,794,000)$ & $147.67 \%$ & $29.28 \%$ \\
\hline Basin Water Reports & $\$ 12,500,000$ & $(\$ 13,208,500)$ & $94.64 \%$ & $29.00 \%$ \\
\hline Acxiom Corporation & $\$ 52,200,000$ & $\$ 70,740,000$ & $73.79 \%$ & $-0.16 \%$ \\
\hline Aspen Technology & $\$ 41,000,000$ & $\$ 69,060,000$ & $59.37 \%$ & $2.48 \%$ \\
\hline Integral Systems Inc. & $\$ 10,000,000$ & $\$ 18,174,000$ & $55.02 \%$ & $1.14 \%$ \\
\hline CoActive Marketing Group & $\$ 977,000$ & $(\$ 1,801,615)$ & $54.23 \%$ & $8.79 \%$ \\
\hline Taleo Corporation & $\$ 320,000$ & $\$ 627,500$ & $51.00 \%$ & $4.19 \%$ \\
\hline Michael Baker Corp & $\$ 9,000,000$ & $\$ 19,300,000$ & $46.63 \%$ & $23.63 \%$ \\
\hline GSI Group Inc & $\$ 9,176,000$ & $\$ 20,393,500$ & $44.99 \%$ & $1.35 \%$ \\
\hline Navistar & Pro forma $\$ 60,000,000$ & $\$ 134,000,000$ & $44.78 \%$ & $5.45 \%$ \\
\hline Overstock.com & $\$ 12,900,000$ & $(\$ 31,433,000)$ & $41.04 \%$ & $12.33 \%$ \\
\hline Grubb \& Elliss & $\$ 5,000,000$ & $\$ 18,468,000$ & $27.07 \%$ & $-4.76 \%$ \\
\hline On2 Technologies Inc. & $\$ 1,199,000$ & $(\$ 6,904,000)$ & $17.37 \%$ & $13.48 \%$ \\
\hline Royal Gold, Inc & $\$ 3,100,000$ & $\$ 21,397,000$ & $14.49 \%$ & $1.43 \%$ \\
\hline VocalTec Communications & $\$ 1,100,000$ & $(\$ 14,142,000)$ & $7.78 \%$ & $3.70 \%$ \\
\hline GeoEye, Inc. & $\$ 2,132,000$ & $\$ 32,900,000$ & $6.48 \%$ & $12.00 \%$ \\
\hline NextWave Wireless & $\$ 5,200,000$ & $(\$ 105,020,000)$ & $4.95 \%$ & $1.71 \%$ \\
\hline
\end{tabular}

Source: WallStreetJournal.com, CNN.com, News.Search.Yahoo.com/news, ProQuest database, and News.Google.com

\section{Scenario 3 - Goods Sold on Layaway}

Company $\mathrm{Z}$ offers layaway sales to its customers. It collects an initial cash deposit from the customers but retains the merchandise and sets it aside from other inventory. Although a date is specified to when the customer must finalize the purchase, Company $\mathrm{Z}$ does not require the customer to sign a fixed payment agreement for the sale. The merchandise is not released to the customer until full payment is received. Company $\mathrm{Z}$ would like to recognize revenue equal to a pro rata portion of the merchandise sales price as cash is collected. The SEC's policy is that Company $\mathrm{Z}$ should postpone recognizing revenue until merchandise is delivered to the customer. Until the delivery, the cash received from the customer should be considered a liability, such as Deposits from Layaway Customers. This treatment is because Company $\mathrm{Z}$ retains the risk of ownership and does not have an enforceable right to the remainder of the purchase price.

\section{Scenario 4 - Nonrefundable Up-front Fees}

Company R, an internet service provider negotiated an agreement with customers to pay up-front nonrefundable "initiation" or "activation" fee at the start of their service. Following the enrollment in the service, these customers will be charged a monthly usage fee that covers the company's operating costs and then some. The nonrefundable activation fee also covers more than the costs to the company. Company $\mathrm{R}$ would like to recognize all of the nonrefundable start-up fees at the time they are paid. The SEC rules that "unless the up-front fee is in exchange for products delivered or services performed that represent the culmination of a separate earnings process, 
deferral of revenue is appropriate because services have not been rendered." In these circumstances, the up-front fee should be pro rated over the entire life of the service agreement, even if it is nonrefundable.

In our study, we found just one company (listed in Table 3) that specifically had this type of error. It is probable that some of the companies included in Scenario \#2 may have had this scenario as well when improperly reporting revenues from complex sales arrangements.

Table 3: Company that belongs to Scenario 4

\begin{tabular}{|l|c|c|c|c|}
\hline Company Name & $\begin{array}{c}\text { Amount of } \\
\text { Restatement }\end{array}$ & $\begin{array}{c}\text { Income in } \\
\text { Restatement } \\
\text { Periods }\end{array}$ & $\begin{array}{c}\text { Restate to } \\
\text { Net Income } \\
\text { Ratio }\end{array}$ & $\begin{array}{c}\text { Drop in } \\
\text { Stock } \\
\text { Price }\end{array}$ \\
\hline IntegraMed America & $\$ 832,000$ & $\$ 2,671,000$ & $31.15 \%$ & $12.00 \%$ \\
\hline
\end{tabular}

Source: WallStreetJournal.com, CNN.com, News.Search.Yahoo.com/news, ProQuest database, and News.Google.com

\section{Scenario 5 - Gross versus Net Basis for Internet Resellers}

Rider.com Company is an Internet company that sells concert tickets to customers. Customers place orders by selecting the specific music group from Rider.com's web site and providing a credit card number for payment. Rider.com received the order and credit card authorization and passes the information along to the concert venue. The venue then sends the tickets directly to the customers. Rider.com never takes title of the tickets and, therefore has no ownership risk or other responsibility for the tickets. They are simply an internet based ticket broker. The concert venues are the ones fully responsible for all returned tickets and disputes. The average ticket price is $\$ 500$, of which Rider.com receives a $\$ 25$ commission. In the event that a credit card is rejected, Rider.com sustains the loss of the commission. Rider.com would like to report revenue from this transaction on a "gross" basis at $\$ 500$, with a $\$ 475$ cost of sales. The SEC disagrees with this treatment and believes that Rider.com should report this transaction on a "net" basis of $\$ 25$ as commission revenue and $\$ 0$ as a cost of sales (Revsine 149).

SAB 104 was issued during 2003, but a substantial amount of companies have continued to restate their earnings in relation to these scenarios. Earnings restatements made because of revenue recognition errors can have a detrimental effect on a company. Investor confidence in the earnings quality of the company can be impaired and the stock price can suffer dearly.

\section{ANALYSIS OF COMPANIES CATEGORIZED BY INDUSTRY}

Overall, the industry most strongly affected by revenue restatements in Table 4 was Healthcare and Pharmaceutical, not technology or telecommunications as might have been expected. There were seven companies in this segment, and most of their restatements related to deferred income, particularly up-front fees and long-term contracts (Scenarios 2 and 4 above). For example, IntegraMed charged an up-front fee on its fertility services. This fee was refundable if the patient did not have a baby. IntegraMed had been recognizing this revenue after the IV procedure was completed, but it was determined that they should be deferring it until after birth. The largest restatement, however, was by Arthrocare, which had treated two companies as distributors when they were actually acting as sales agents. As such, revenue should have been recognized at the time they performed procedures, rather than at the time Arthrocare shipped goods to them to be used for the procedures. This caused a restatement of over $\$ 28$ million and their stock plummeted by $42 \%$.

We found that the gross amount of the restatement did not affect the stock price as much as other factors. For companies in Table 4 where the restatement was a small percentage of total revenues such as GeoEye (a correction of $\$ 2$ million among $\$ 183$ million of sales revenue) the market barely blinked with a mere $2 \%$ drop. Whereas, IntegraMed's stock dropped by $12 \%$ by a mere deferral of $\$ 2$ million in revenue. The $\$ 9$ million correction for GSI Group (out of total revenues over $\$ 500$ million) was related to timing issues which their audit committee reports have been corrected and the customers related to those accounts have since paid. With this announcement, the stock only fell $1.35 \%$. The most unique of the restatements was Navistar. Their stock price increased by $5 \%$ following an announcement of restatement in their pro forma earnings. The actual misstatement to their GAAP revenue was little to none. 
The largest drops, as shown in Table 4, were usually connected to companies where the restatement announcement was coupled with other bad news. For instance, Medicis had one of the smallest announcements related to their returns on allowances. Although they did not specify the amount, their entire returns on allowance account was \$542,000, which would place it much lower than most of the other restatements in the study. Unfortunately, this announcement put more scrutiny on the company by investors, who realized that their product lines, although profitable, are not selling as well as their competitors. Their stock price fell $24 \%$ in less than a week. Even greater was MRV Communication's drop of $26 \%$. It has been over a year since their announcement that they would restate their financials for prior years, and they still have not done so. It is also troubling to investors that as a result of their not having completed this filing and not holding shareholder's meetings, they have been removed from NASDAQ and put on the pink sheets.

Table 4: Companies Categorized by Industry

\begin{tabular}{|c|c|c|c|c|c|}
\hline \multirow{2}{*}{ Industry } & \multirow{2}{*}{ Company Name } & \multicolumn{2}{|c|}{ Announcement } & \multirow{2}{*}{$\begin{array}{c}\text { Amount of } \\
\text { Restatement }\end{array}$} & \multirow{2}{*}{$\begin{array}{c}\text { Drop in } \\
\text { Stock Price }\end{array}$} \\
\hline & & Ticker & Date & & \\
\hline \multicolumn{6}{|c|}{ TECHNOLOGY } \\
\hline & Aspen Technology & AST & $05 / 15 / 09$ & $\$ 41,000,000$ & $2.48 \%$ \\
\hline & Integral Systems Inc. & ISYS & $12 / 11 / 08$ & $\$ 10,000,000$ & $1.14 \%$ \\
\hline & Cadence Design Systems & CDNS & $12 / 10 / 08$ & $\$ 24,800,000$ & $29.28 \%$ \\
\hline & Acxiom Corporation & ACXM & $05 / 14 / 08$ & $\$ 52,200,000$ & $-0.16 \%$ \\
\hline & Taleo Corporation & TLEO & $02 / 23 / 09$ & $\$ 320,000$ & $4.19 \%$ \\
\hline & Insight Enterprises Inc & NSIT & $02 / 09 / 09$ & $\$ 60,000,000$ & $48.31 \%$ \\
\hline & Verifone & PAY & $12 / 03 / 07$ & $\$ 70,000,000$ & $48.80 \%$ \\
\hline & Isilon Systems, Inc & ISLN & $02 / 29 / 08$ & $\$ 7,000,000$ & $4.10 \%$ \\
\hline & GSI Group Inc & GSIG & $01 / 06 / 09$ & $\$ 9,176,000$ & $1.35 \%$ \\
\hline & GeoEye, Inc. & GEOY & $03 / 17 / 09$ & $\$ 2,132,000$ & $12.00 \%$ \\
\hline & & \multicolumn{2}{|c|}{ AVERAGE: } & $\$ 27,662,800$ & $15.15 \%$ \\
\hline \multicolumn{6}{|c|}{ TELECOMMUNICATIONS } \\
\hline & VocalTec Communications & VOCL & $05 / 27 / 08$ & $\$ 1,100,000$ & $3.70 \%$ \\
\hline & MRV Communications & MRVC & $06 / 05 / 08$ & Unreported & $26.00 \%$ \\
\hline & EF Johnson & EFJI & $03 / 31 / 09$ & $\$ 3,400,000$ & $12.50 \%$ \\
\hline & NextWave Wireless & WAVE & $03 / 24 / 07$ & $\$ 5,200,000$ & $1.71 \%$ \\
\hline & & \multicolumn{2}{|c|}{ AVERAGE: } & $\$ 3,233,333$ & $10.98 \%$ \\
\hline \multicolumn{6}{|c|}{\begin{tabular}{|l} 
HEALTHCARE AND PHARMACEUTICAL \\
\end{tabular}} \\
\hline & NutraCea Inc. & NTRZ & $02 / 23 / 09$ & $\$ 4,600,000$ & $17.14 \%$ \\
\hline & ArthroCare & ARTC & $07 / 21 / 08$ & $\$ 28,000,000$ & $42.02 \%$ \\
\hline & Medicis & MRX & $09 / 24 / 08$ & Under $\$ 500,000$ & $24.00 \%$ \\
\hline & WellCareHealth Plans & WCG & $07 / 21 / 08$ & $\$ 42,000,000$ & $7.38 \%$ \\
\hline & IntegraMed America, Inc & INMD & $03 / 17 / 09$ & $\$ 2,132,000$ & $12.00 \%$ \\
\hline & Skilled Healthcare Group & SKG & $06 / 10 / 09$ & $\$ 8,000,000$ & $19.00 \%$ \\
\hline & Apogee Technology, Inc & ATCS & $05 / 15 / 09$ & $\$ 250,000$ & $7.14 \%$ \\
\hline & & \multicolumn{2}{|c|}{ AVERAGE: } & $\$ 14,163,667$ & $18.38 \%$ \\
\hline \multicolumn{6}{|c|}{ BUSINESS AND MARKETING SERVICES } \\
\hline & CoActive Marketing Group & CMKG & $05 / 11 / 09$ & $\$ 977,000$ & $8.79 \%$ \\
\hline & On2 Technologies Inc. & ONT & $05 / 27 / 08$ & $\$ 1,199,000$ & $13.48 \%$ \\
\hline & Michael Baker Corp & BKR & $02 / 22 / 08$ & $\$ 11,300,000$ & $23.63 \%$ \\
\hline & & \multicolumn{2}{|c|}{ AVERAGE: } & $\$ 4,492,000$ & $15.30 \%$ \\
\hline \multicolumn{6}{|c|}{ MISCELLANEOUS } \\
\hline & Sunrise Real Estate Group & SRRE & $08 / 28 / 08$ & $\$ 157,811$ & $0.00 \%$ \\
\hline & Royal Gold, Inc & RGLD & $11 / 04 / 08$ & $\$ 3,100,000$ & $1.43 \%$ \\
\hline & Overstock.com & OSTK & $10 / 23 / 08$ & $\$ 12,900,000$ & $12.33 \%$ \\
\hline & Grubb \& Elliss & GBE & $03 / 18 / 09$ & $\$ 5,000,000$ & $4.76 \%$ \\
\hline & Navistar & NAV & $12 / 24 / 08$ & Pro forma $\$ 60,000,000$ & $-5.45 \%$ \\
\hline & Basin Water Reports & BWTR & $02 / 11 / 09$ & $\$ 12,500,000$ & $29.00 \%$ \\
\hline & & \multicolumn{2}{|c|}{ AVERAGE: } & $\$ 6,731,562$ & $7.01 \%$ \\
\hline
\end{tabular}

Source: WallStreetJournal.com, CNN.com, News.Search.Yahoo.com/news, ProQuest database, and News.Google.com

Because of these inconsistencies with the correlation of restatement amount to the drop of stock price, the numbers are reconstructed into the table below which calculates the amount of restatement, the amount of net income to the same periods, and the ratio between the two. The respective ratios shown in Table 5 are then compared to stock price drops. 
Table 5: Comparison of the Ratio of Restatement to Net Income with the Ratio of Stock Price Drop

\begin{tabular}{|c|c|c|c|c|}
\hline Company Name & $\begin{array}{c}\text { Amount of } \\
\text { Res tatement }\end{array}$ & $\begin{array}{c}\text { Income in } \\
\text { Res tatement } \\
\text { Periods } \\
\end{array}$ & \begin{tabular}{|c|} 
Restate to \\
Net Income \\
Ratio \\
\end{tabular} & $\begin{array}{c}\text { Drop in } \\
\text { Stock } \\
\text { Price } \\
\end{array}$ \\
\hline MRV Communications & N/A & $(\$ 15,622,000)$ & & $26.00 \%$ \\
\hline Verifone & $\$ 70,000,000$ & $(\$ 34,016,000)$ & $205.79 \%$ & $48.80 \%$ \\
\hline WellCareHealth Plans Inc & $\$ 42,000,000$ & $(\$ 26,833,000)$ & $156.52 \%$ & $7.38 \%$ \\
\hline Insight Enterprises Inc & $\$ 60,000,000$ & $(\$ 39,555,000)$ & $151.69 \%$ & $48.31 \%$ \\
\hline Cadence Design Systems & $\$ 24,800,000$ & $(\$ 16,794,000)$ & $147.67 \%$ & $29.28 \%$ \\
\hline Basin Water Reports & $\$ 12,500,000$ & $(\$ 13,208,500)$ & $94.64 \%$ & $29.00 \%$ \\
\hline \begin{tabular}{|l|} 
ArthroCare \\
\end{tabular} & $\$ 28,000,000$ & $\$ 37,427,500$ & $74.81 \%$ & $42.02 \%$ \\
\hline Acxiom Corporation & $\$ 52,200,000$ & $\$ 70,740,000$ & $73.79 \%$ & $-0.16 \%$ \\
\hline Aspen Technology & $\$ 41,000,000$ & $\$ 69,060,000$ & $59.37 \%$ & $2.48 \%$ \\
\hline Integral Systems Inc. & $\$ 10,000,000$ & $\$ 18,174,000$ & $55.02 \%$ & $1.14 \%$ \\
\hline CoActive Marketing Group & $\$ 977,000$ & $(\$ 1,801,615)$ & $54.23 \%$ & $8.79 \%$ \\
\hline Skilled Healthcare Group & $\$ 8,000,000$ & $\$ 15,311,600$ & $52.25 \%$ & $19.00 \%$ \\
\hline Taleo Corporation & $\$ 320,000$ & $\$ 627,500$ & $51.00 \%$ & $4.19 \%$ \\
\hline Michael Baker Corp & $\$ 9,000,000$ & $\$ 19,300,000$ & $46.63 \%$ & $23.63 \%$ \\
\hline GSI Group Inc & $\$ 9,176,000$ & $\$ 20,393,500$ & $44.99 \%$ & $1.35 \%$ \\
\hline Navistar & Pro forma $\$ 60,000,000$ & $\$ 134,000,000$ & $44.78 \%$ & $5.45 \%$ \\
\hline Overstock.com & $\$ 12,900,000$ & $(\$ 31,433,000)$ & $41.04 \%$ & $12.33 \%$ \\
\hline NuraCea Inc. & $\$ 4,600,000$ & $\$ 11,911,000$ & $38.62 \%$ & $17.14 \%$ \\
\hline IntegraMed America, Inc & $\$ 832,000$ & $\$ 2,671,000$ & $31.15 \%$ & $12.00 \%$ \\
\hline Grubb \& Ellis s & $\$ 5,000,000$ & $\$ 18,468,000$ & $27.07 \%$ & $-4.76 \%$ \\
\hline On2 Technologies Inc. & $\$ 1,199,000$ & $(\$ 6,904,000)$ & $17.37 \%$ & $13.48 \%$ \\
\hline Royal Gold, Inc & $\$ 3,100,000$ & $\$ 21,397,000$ & $14.49 \%$ & $1.43 \%$ \\
\hline Isilon Systems, Inc & $\$ 7,000,000$ & $\$ 62,300,000$ & $11.24 \%$ & $4.10 \%$ \\
\hline EF Johnson & $\$ 3,400,000$ & $(\$ 30,986,000)$ & $10.97 \%$ & $12.50 \%$ \\
\hline Apogee Technology, Inc & $\$ 250,000$ & $\$ 2,952,387$ & $8.47 \%$ & $7.14 \%$ \\
\hline VocalTec Communications & $\$ 1,100,000$ & $(\$ 14,142,000)$ & $7.78 \%$ & $3.70 \%$ \\
\hline GeoEye, Inc. & $\$ 2,132,000$ & $\$ 32,900,000$ & $6.48 \%$ & $12.00 \%$ \\
\hline NextWave Wireless & $\$ 5,200,000$ & $(\$ 105,020,000)$ & $4.95 \%$ & $1.71 \%$ \\
\hline Sunrise Real Estate Group & $\$ 157,811$ & $\$ 4,766,000$ & $3.31 \%$ & $0 \%$ \\
\hline
\end{tabular}

Source: WallStreetJournal.com, CNN.com, News.Search.Yahoo.com/news, ProQuest database, and News.Google.com

Here is a stronger correlation between the amount of the drop and the percentage of the restatement to the earnings of the company, as might be expected. Figure 4 illustrates the correlation between the amount of the drop and the percentage of the restatement to the earnings.

Figure 4: Correlation between Amount of the Drop and the Percentage of the Restatement to Earnings

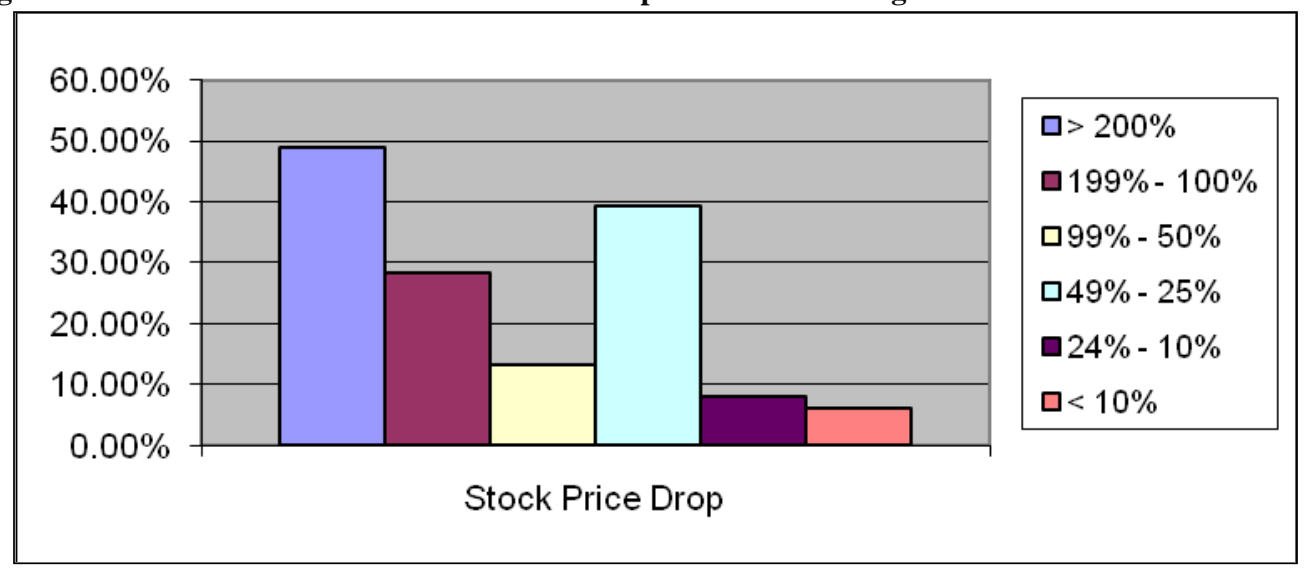

Source: WallStreetJournal.com, CNN.com, News.Search.Yahoo.com/news, ProQuest database, and News.Google.com 


\section{CONCLUSION}

The continuous earnings restatements made by companies since the guidance releases of SAB 101, 104, and the Sarbanes Oxley Act of 2002 have caused concern among investors. Several companies are still claiming accounting errors in revenue recognition that were clearly spelled out half a decade ago. Skepticism in earnings restatements caused from revenue recognition errors can be observed by the decrease in stock price following an earnings restatement announcement. Companies should observe the effect of their earnings restatements on the market. In some cases, these earnings restatements have resulted in complete revocation from the stock market itself. Revenue restatements appear to be more prevalent within certain industries, and regulators should issue sticker guidelines to these industries directly to reduce the apparent confusion.

\section{AUTHOR INFORMATION}

Yiou Zhu, a Master of Accountancy graduate at Rider University in Lawrenceville, N.J., and a faculty at Shanghai Sanda Institute, Shanghai, China, email: zhuyio@ rider.edu

Jodi Kleuskens, a Master of Accountancy graduate at Rider University in Lawrenceville, N.J., email: kleuskens@rider.edu

Gloria Grebis, a Master of Accountancy graduate at Rider University in Lawrenceville, N.J., email: grebis@rider.edu

\section{REFERENCES}

1. Baker to Restate 2006 Financial Results are Part of Previously Announced 2007 Restatement. iStockAnalyst.com. 10 June 2008.

2. Best Practices in Revenue Reporting: Revenue Reporting Edition. RevenueRecognition.com. Financial Executive Benchmarking Survey.

3. Bill and Holds.” Financial Education. http://financial -education.com/2007/10/02/bill-and-holds-sales.

4. CoActive Marketing Restates Financial Statements and Reports Results for the Nine Months Ended December 31, 2006.” BNet.com. 21 Mar 2007.

5. GeoEye Release Second Quarter 2008 Earnings and Explanation of Financial Restatements. Reuters.com. 12 Aug 2008.

6. $\quad$ Gonzales, Angela (2009). "NutraCea Inc. to restate 2007, 2008 Financials.” Phoenix Business.

7. Hermanson, Dana R and Daniel M. Ivancevich, Susan H. Ivancevich(2008). "SOX Section 404 Material Weaknesses Related to Revenue Recognition.” The CPA Journal. New York: Vol. 78, Iss. 10. Pg. 40.

8. http://ir.taleo.com, News.

9. Kanaracus, Chris (2008). “Overstock.com Restates Earnings, Cites ERP Implementation,” PCW Business Center.

10. Navistar to Restate Results for the First Nine Months of Fiscal Bloomberg.com.

11. Revsine, Lawrence and Daniel Collins, Bruce Johnson, Fred Mittelstaedt (2008). Financial Reporting \& Analysis. 4th Ed Prentice Hall. Upper Saddle River, New Jersey 07458.

12. Risks in Revenue Reporting: Risk Edition. RevenueRecognition.com. Financial Executive Benchmarking Survey.

13. Schatz nobel Izard P.C. Announces Class Action Lawsuit Against MRV Communications, Inc. Globalnewswire.com. 9 Jul 2008.

14. Standard \& Poors NetAdvantage.

15. Stockfisch, Jerome (2008). "WellCare Health Plans Admits Accounting Errors." The Tampa Tribune. www.tbo.com.

16. Update 1 - IntegraMed Delays Annual Filing Due to Accounting Issue. BNet.com. 17 Mar 2009.

17. Wilson, Wendy M (2008). "An Empirical Analysis of the Decline in the Information Content of Earnings Following Restatements." The Accounting Review. Vol. 83, No.2. 


\section{NOTES}

